\title{
Role of Chest Ultrasound in Detecting Successful Pleurodesis in Patients with Malignant Pleural Effusion \\ Nabil Farouk Awad ${ }^{1}$, Abd-Allah Mohammad ElBalsha ${ }^{1}$, Wafik Ebrahim Aly ${ }^{2}$, Emad Khamis Ahmed Seddik ${ }^{1}$ \\ ${ }^{1}$ Department of Chest Diseases, ${ }^{2}$ Department of Radiodiagnosis, Faculty of Medicine, Al-Azhar University (Cairo), Egypt \\ Corresponding author: Emad Khamis Ahmed Seddik, Email: dr_emad_2020@yahoo.com
}

\begin{abstract}
Background: One of the easiest sign to identify during chest sonography is the movement of the visceral pleura compared to immobility of the parietal pleura. This sign of 'pleural sliding', firstly described in veterinary medicine and was used to exclude the presence of pneumothorax when present and to suspect atelectasis, fibrosis or pleural adhesions (pleurodesis) when absent.

Aim of the Work: This study aims to detect successful pleurodesis with povidone-iodine in patients with malignant pleural effusion by using the chest ultrasonography.

Subjects and Methods: This study was carried out on 30 patients with malignant pleural effusion attended to AL-Hussein University hospital, Al-Azhar University in the period between October 2017 and May 2018.All patients underwent full history taking, complete clinical examination, plain chest X-ray, routine lab investigations, CT scan of the chest, pleural fluid analysis including physical, chemical, Bacteriological and cytological examination for malignant cells, medical thoracoscopy, transthoracic ultrasonography before and after pleurodesis to assess the presence or absence of sliding sign.

Results: The results of this study revealed that the transthoracic ultrasound can easily detect sliding sign and assess the success of pleurodesis. Iodopovidone was effective in inducing pleurodesis in patients with malignant pleural effusion.

Conclusion: Transthoracic ultrasound for the evaluation of pleurodesis is feasible and simple. Iodopovidone was effective in inducing pleurodesis in patients with malignant pleural effusion.
\end{abstract}

Keywords: Transthoracic ultrasound, Sliding sign, Pleurodesis.

\section{INTRODUCTION}

Most of the malignant pleural effusions are the result of metastases to the pleura from other sites. The primary tumors were, in the decreasing order of frequency: lung (37\%), breast (17\%), unknown site $(10 \%)$, lymphoma $(9 \%)$, gastrointestinal $(8 \%)$, ovary $(7 \%)$ and mesothelioma $(3 \%)^{(1)}$.

Management of malignant effusions depends on palliation of dyspnea and prevention of the reaccumulation of pleural fluid to provide the highest possible quality of life, regardless of the need for other treatment modalities ${ }^{(2)}$.

Pleurodesis is defined as the symphysis between the visceral and parietal pleural surfaces; its function is to prevent accumulation of either air or fluid into the pleural space. Effusions of malignant origin are the most common indication for pleurodesis ${ }^{(3)}$.

Unfortunately, pleurodesis fails in 10-40\% of patients with recurrence of pleural fluid and dyspnea. Because pleurodesis is associated with considerable cost and morbidity, the identification of patients who will experience an unsuccessful pleurodesis would be desirable ${ }^{(4)}$.

The chest ultrasound can easily visualize pleural effusions and help in identifying malignant effusion. Sonographic criteria of malignant effusions include diaphragmatic and parietal pleura nodule or nodules, pleural thickening $1 \mathrm{~cm}$ or more and hepatic metastasis.

Thoracic ultrasonography easily detects the sign of 'pleural sliding', due to the movement of the visceral pleura on the parietal pleura. This sign is absent when pleurodesis is successful ${ }^{(5)}$.

\section{AIM OF THE WORK}

This study aims to detect successful pleurodesis with povidone-iodine in patients with malignant pleural effusion by using the chest ultrasonography.

\section{SUBJECTS AND METHODS}

This study was carried out on 30 patients with malignant pleural effusion attended to AL-Hussein University hospital, Al-Azhar University in the period between October 2017 and May 2018. They were diagnosed by pleural fluid cytology or tissue biopsy (CTguided, Abrams or thoracoscopic biopsy).Informed consent was obtained from all patients enrolled in the study. All patients underwent full history taking, complete clinical examination, plain chest $\mathrm{X}$-ray, routine lab investigations, CT scan of the chest, pleural fluid analysis including physical, chemical, Bacteriological and cytological examination for malignant cells, medical thoracoscopy and multiple pleural biopsies, histopathological examination, transthoracic ultrasonography before the injection of 
iodopovidone to assess the presence of the sliding sign and pleural fluid in all anatomical areas of the affected side, pleurodesis by 1-Injection of $20 \mathrm{~mL}$ saline plus $30 \mathrm{~mL}$ of $2 \%$ Lidocaine into the pleural space through the intercostal tube. 2-Intercostal tube clamped for 30 minutes and the patient instructed to change his position in bed. 3-Injection of povidone-iodine by injection of mixture of $25 \mathrm{ml}$ of $10 \%$ povidone-iodine and $25 \mathrm{ml}$ of normal saline into the pleural space. 4-Intercostal tube clamped for 2 to 3 hours and the patient instructed to change his position in bed. 5-The tube is then opened and left for 24 hour to drain the injected amount of fluid then removed, Plain chest X-ray after 24 hours, follow up the patients by chest ultrasonography after 24 hours and after one month to detect successful pleurodesis and compare them with sonographic findings before pleurodesis.

Exclusion criteria include: Heavy or densely loculated malignant pleural effusion that mostly need surgical intervention, Recurrent pneumothorax, Recurrent hydrothorax, Atelectasis due to endobronchial obstruction, Haemorrhagic blood diseases.

\section{Ethical consideration}

Ethical clearance was obtained from the Research Ethical Committee at Al-Hussein University Hospital. A signed written informed consent from patients or their relatives was obtained. Privacy and confidentiality were maintained throughout the study process. Subjects or their relatives received written notification of the intervention results.

\section{Statistical analysis:}

Data were statistically described in terms of mean \pm standard deviation $( \pm$ S.D. $)$, or frequencies (number of cases) and percentages when appropriate. Comparison of numerical variables between the study groups was done using Student's $t$ test. For comparing categorical data, Chi square (v2) test was performed.

For all the above-mentioned statistical tests, the threshold of significance is fixed at the 5\% level (P-value), a $\mathrm{P}$-value $\geq 0.05$ indicates non-significant results, a $P$-value $<0.05$ indicates significant results, a $\mathrm{P}$-value $<0.01$ indicates highly significant results, and a P-value $<0.001$ indicates very high significant results.

All statistical calculations were done using computer program SPSS (Statistical Package for the
Social Science; SPSS Inc., Chicago, IL, USA) version 15 for Microsoft Windows.

\section{RESULTS}

This study was carried out on 30 patients attended to Hussein University hospital, Al-Azhar University, in which 30 patients presented with malignant pleural effusion. They included 18 males and 14 females. This study was designed to evaluate the feasibility of pleurodesis assessment by chest ultrasonography. In this study chest ultrasound was performed to the patients before pleurodesis and can demonstrate the presence or the absence of sliding sign at different areas of the affected hemithorax also can demonstrate the amount of pleural effusion. After pleurodesis was done, the chest ultrasound can assess loss of sliding sign and pleural fluid in patients with effective pleurodesis and persistence of it in patients with failed pleurodesis.

Table (1): Comparison of mammary areas before and after pleurodesis.

\begin{tabular}{|c|c|c|c|c|}
\hline \multicolumn{2}{|c|}{ Mammary areas } & $\begin{array}{c}\text { Before } \\
\text { pleurodesis } \\
(\mathbf{N}=\mathbf{3 0})\end{array}$ & $\begin{array}{c}\text { After } \\
\text { pleurodesis } \\
(\mathbf{N}=\mathbf{3 0})\end{array}$ & p-value \\
\hline 产离 & $\begin{array}{l}\text { Sliding } \\
\text { No sliding }\end{array}$ & $\begin{array}{l}22(73 \%) \\
8(27 \%)\end{array}$ & $\begin{array}{l}5(17 \%) \\
25(83 \%)\end{array}$ & $<0.001 *$ \\
\hline 苞 & $\begin{array}{l}\text { Sliding } \\
\text { No sliding } \\
\text { Moderate } \\
\text { effusion } \\
\end{array}$ & $\begin{array}{c}25(83 \%) \\
2(7 \%) \\
3(10 \%)\end{array}$ & $\begin{array}{c}7(23 \%) \\
23(77 \%) \\
0(0 \%)\end{array}$ & $<0.001 *$ \\
\hline 㞼 & $\begin{array}{l}\text { Sliding } \\
\text { No sliding } \\
\text { Mild effusion } \\
\text { Moderate } \\
\text { effusion }\end{array}$ & $\begin{array}{c}9(30 \%) \\
0(0 \%) \\
9(30 \%) \\
12(40 \%)\end{array}$ & $\begin{array}{c}1(3 \%) \\
26(87 \%) \\
3(10 \%) \\
0(0 \%)\end{array}$ & $<0.001 *$ \\
\hline
\end{tabular}

*: P-value $<0.001$ is considered highly significant.

This table shows highly statistical significant difference ( $p$-value < 0.001) between mammary areas before and after pleurodesis.

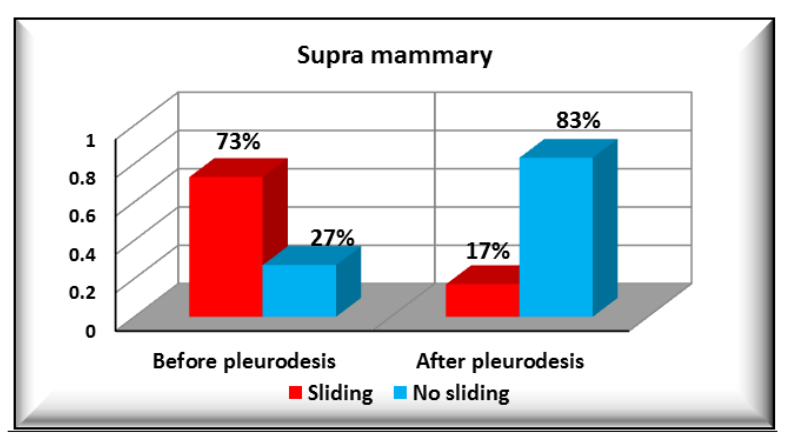

Figure (1): Supra-mammary area before and after pleurodesis. 


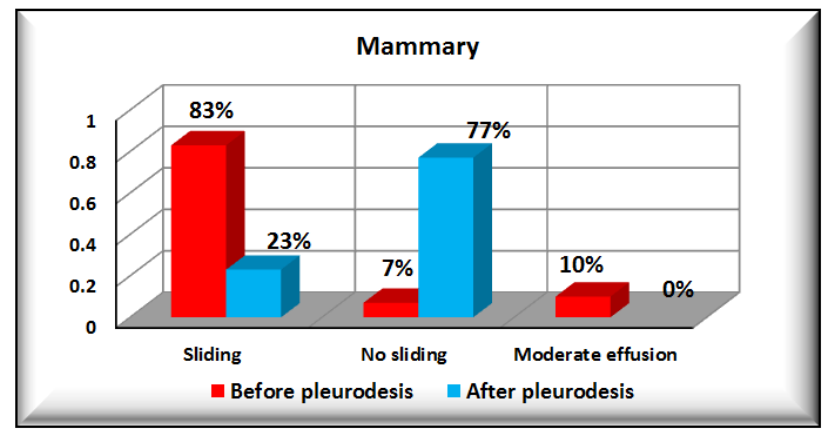

Figure (2): Mammary area before and after pleurodesis.

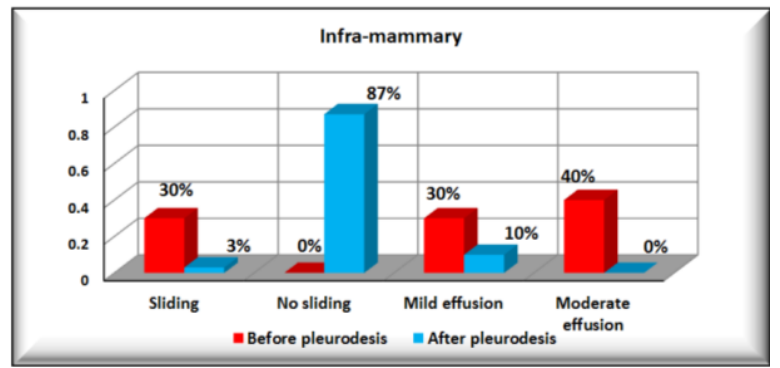

Figure (3): Infra-mammary area before and after pleurodesis.

Table (2): Comparison of axillary areas before and after pleurodesis.

\begin{tabular}{|c|c|c|c|c|}
\hline \multicolumn{2}{|c|}{ Axillary areas } & $\begin{array}{c}\text { Before } \\
\text { pleurodesis } \\
(\mathbf{N}=\mathbf{3 0})\end{array}$ & $\begin{array}{c}\text { After } \\
\text { pleurodesis } \\
(\mathbf{N}=\mathbf{3 0})\end{array}$ & p-value \\
\hline 总苟 & $\begin{array}{l}\text { Sliding } \\
\text { No sliding }\end{array}$ & $\begin{array}{l}24(80 \%) \\
6(20 \%)\end{array}$ & $\begin{array}{c}6(20 \%) \\
24(80 \%)\end{array}$ & $<0.001 *$ \\
\hline 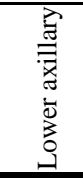 & $\begin{array}{l}\text { Sliding } \\
\text { No sliding } \\
\text { Mild effusion } \\
\text { Moderate } \\
\text { effusion }\end{array}$ & $\begin{array}{c}3(10 \%) \\
0(0 \%) \\
12(40 \%) \\
15(50 \%)\end{array}$ & $\begin{array}{c}0(0 \%) \\
26(86 \%) \\
2(7 \%) \\
2(7 \%)\end{array}$ & $<0.001 *$ \\
\hline
\end{tabular}

*: P-value $<0.001$ is considered highly significant.

This table shows highly statistical significant difference ( $\mathrm{p}$-value < 0.001 ) between axillary areas before and after pleurodesis.

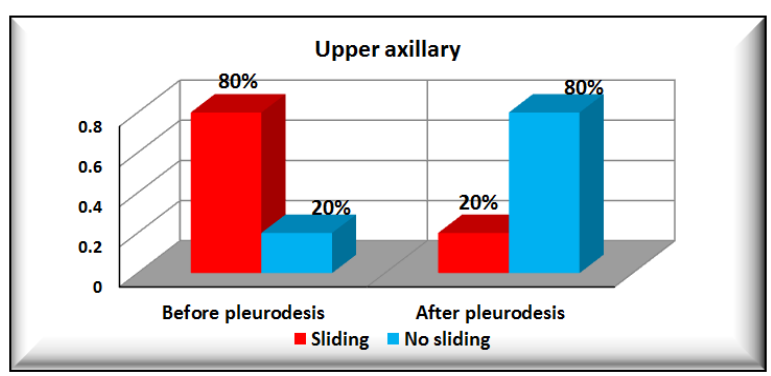

Figure (4): Upper axillary area before and after pleurodesis.

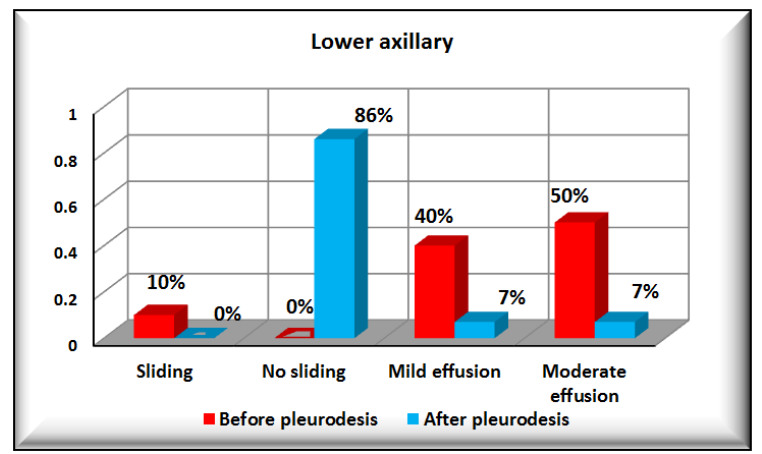

Figure (5): Lower axillary area before and after pleurodesis.

Table (3): Comparison of scapular areas before and after pleurodesis:

\begin{tabular}{|c|c|c|c|c|}
\hline \multicolumn{2}{|c|}{ Scapular areas } & $\begin{array}{c}\begin{array}{c}\text { Before } \\
\text { pleurodesis } \\
(\mathbf{N}=\mathbf{3 0})\end{array} \\
\end{array}$ & $\begin{array}{c}\text { After } \\
\text { pleurodesis } \\
(\mathbf{N}=\mathbf{3 0})\end{array}$ & p-value \\
\hline 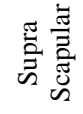 & $\begin{array}{l}\text { Sliding } \\
\text { No sliding }\end{array}$ & $\begin{array}{l}25(83 \%) \\
5(17 \%)\end{array}$ & $\begin{array}{c}9(30 \%) \\
21(70 \%)\end{array}$ & $<0.001^{*}$ \\
\hline 离 & $\begin{array}{l}\text { Sliding } \\
\text { No sliding } \\
\text { Moderate } \\
\text { effusion }\end{array}$ & $\begin{array}{c}23(77 \%) \\
44(13 \%) \\
3(10 \%)\end{array}$ & $\begin{array}{c}1(3 \%) \\
29(97 \%) \\
0(0 \%)\end{array}$ & $<0.001^{*}$ \\
\hline 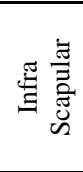 & $\begin{array}{l}\text { Sliding } \\
\text { No sliding } \\
\text { Mild effusion } \\
\text { Moderate } \\
\text { effusion }\end{array}$ & $\begin{array}{c}11(37 \%) \\
0(0 \%) \\
3(10 \%) \\
16(53 \%)\end{array}$ & $\begin{array}{c}0(0 \%) \\
27(90 \%) \\
3(10 \%) \\
0(0 \%)\end{array}$ & $<0.001^{*}$ \\
\hline
\end{tabular}

*: P-value $<0.001$ is considered highly significant.

This table shows highly statistical significant difference ( $p$-value $<0.001$ ) between scapular areas before and after pleurodesis.

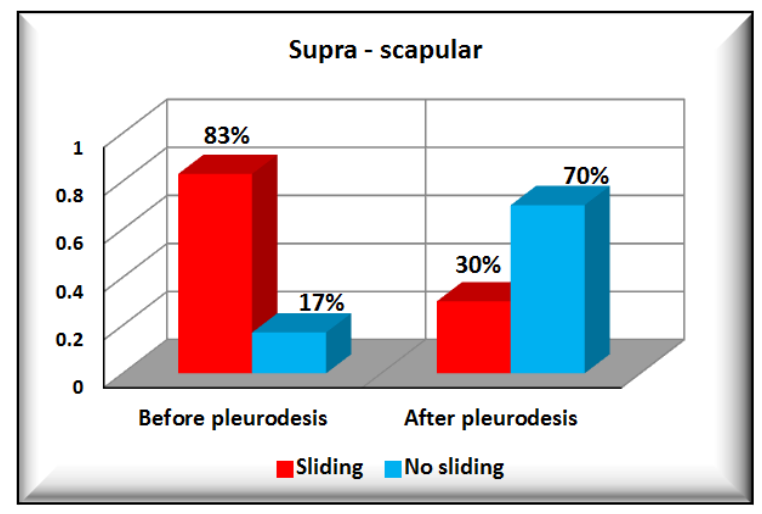

Figure (6): Supra - scapular area before and after pleurodesis. 


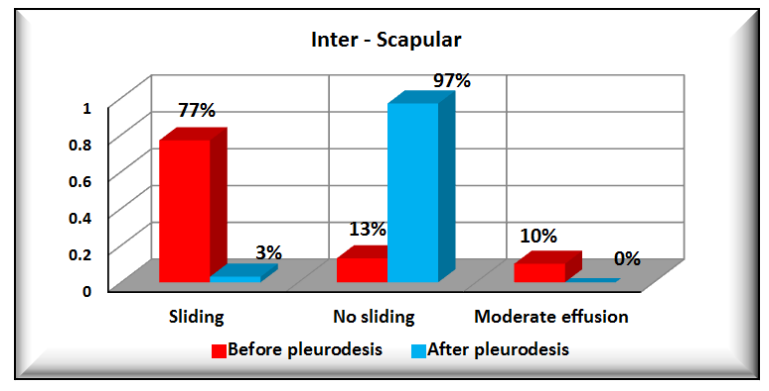

Figure (7): Inter - scapular area before and after pleurodesis.

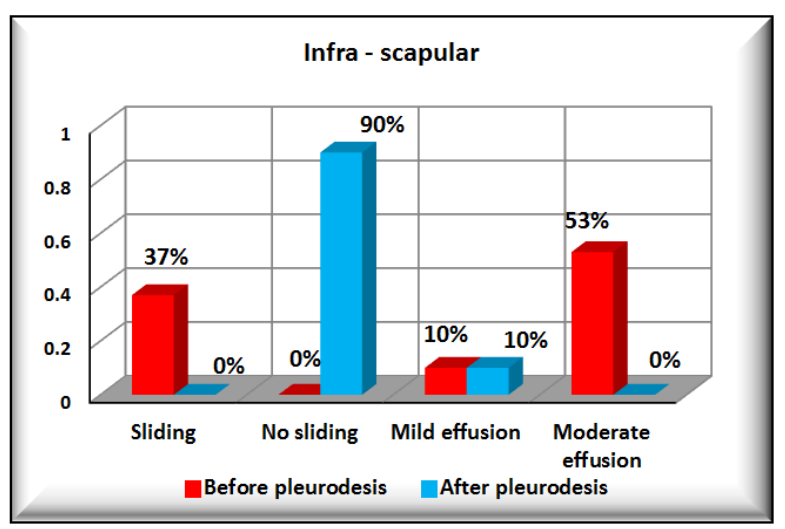

Figure (8): Infra scapular area before and after pleurodesis.

Table (4): Distribution of patients according to success or failure of pleurodesis by povidone iodine.

\begin{tabular}{|l|l|c|}
\hline \multicolumn{2}{|c|}{} & $\begin{array}{c}\text { Studied patients } \\
(\mathbf{N}=30)\end{array}$ \\
\hline \multirow{2}{*}{ Outcome } & Failed & $4(13 \%)$ \\
\cline { 2 - 3 } & Successful & $26(87 \%)$ \\
\hline
\end{tabular}

This table shows description of outcome in studied patients. 4 of studied patients (13\%) failed while 26 patients $(87 \%)$ showed success.

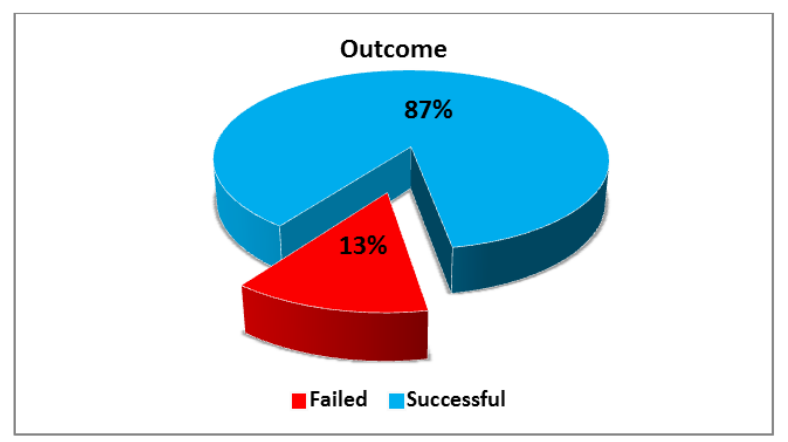

Figure (9): Distribution of patients according to success or failure of pleurodesis by povidone iodine.

\section{DISCUSSION}

The study was conducted in Al Hussein University hospital, Al Azhar University, in which 30 patients presented with malignant pleural effusion. They included 18 males and 14 females. This study was designed to evaluate the feasibility of pleurodesis assessment by chest ultrasonography.

As regard sex of patients in the studied groups, 18 patients $(60 \%)$ were males and 12 patients (40\%) were females. In this study, 17 patients (57\%) were smokers and 13 patients $(43 \%)$ were nonsmokers. In this study, 18 patients $(60 \%)$ had right sided pleural effusion, while 12 patients (40\%) had left sided pleural effusion. This correlates with the study of Kabil et al. They reported that right sided pleural effusion was more common than left side. In their study, $56.67 \%$ of the patients had right sided pleural effusion and $43.33 \%$ of patients had left sided pleural effusion ${ }^{(6)}$.

In this study 16 patients $(60 \%)$ were presented by massive pleural effusion and the other 14 patients were presented by moderate effusion (40\%). Porcel et al. reported that malignancy is the most common cause of effusions that are either large, opacifying more than two thirds of hemithorax, or massive, opacifying the entire hemithorax, it was found as the cause of $55 \%$ of large and massive effusions ${ }^{(7)}$.

In this study the dyspnea was the most common symptom in patients with malignant pleural effusion 30 patients followed by cough 24 patients and chest pain in 19 patients. Chernow et al. reported that the most distressing symptom for these patients is breathlessness, initially with exertion and subsequently at rest ${ }^{(8)}$.

One of the easiest sign to identify during chest sonography is the movement of the visceral pleura compared to immobility of the parietal pleura. This sign of 'pleural sliding', firstly described in veterinary medicine and is used to exclude the presence of pneumothorax when present and to suspect atelectasis, fibrosis or pleural adhesions (pleurodesis) when absent ${ }^{(9)}$.

Sonographic findings were classed following Lichtenstein guidelines as follow:

When the pleural sliding was absent and the lung was seen after the parietal pleural line this means effective pleurodesis.

When pleural sliding was absent and no lung was detected after the parietal pleural line (the 'stratosphere sign') this means pneumothorax.

When an echo free component was detected this means pleural effusion. 
During ultrasonography, the probe was positioned in the intercostal space at 9 different predefined points, 2 on the hemiclavicular line (II and IV intercostal space), 3 on the midaxillary line (II, IV and VI intercostal space) and 4 posteriorly on the midline between the spine and the scapula (II, V, VII and IX intercostal space). Pleurodesis was defined excellent when pleurodesis was confirmed in all the 9 considered points, effective when it was confirmed in more than 6 points, poor when it was confirmed in 6 points or less ${ }^{(10)}$.

In this study chest ultrasound was performed to the patients before pleurodesis and can demonstrate the presence or the absence of sliding sign at different areas of the affected hemithorax also can demonstrate the amount of pleural effusion.

After pleurodesis was done, the chest ultrasound can assess loss of sliding sign and pleural fluid in patients with effective pleurodesis and persistence of it in patients with failed pleurodesis.

In the present study there was a comparison of mammary areas before and after pleurodesis, there was also a comparison of axillary areas before and after pleurodesis and a comparison of scapular areas before and after pleurodesis.

This is correlated with the study of Fayiad et al. who reported that there was highly significance between ultrasound findings before and after the pleurodesis in these areas ${ }^{(11)}$.

In this study 30 patients were subjected to pleurodesis using povidone-iodine $26(87 \%)$ of them showed successful pleurodesis in 30 days follow up by chest ultrasonography with loss of sliding sign. In 4 patients (13\%) pleurodesis failed with sliding sign still present associated with increase in the amount of pleural fluid.

In a study done by Morales-Gomez et al., iodopovidone was used for pleurodesis in 39 patients with malignant pleural effusion, achieving control of effusion in 33 patients $(91.6 \%)^{(12)}$.

\section{CONCLUSION}

The chest ultrasound can easily visualize pleural effusions and help in identifying malignant effusion. The chest ultrasound can be used to detect the success of pleurodesis by using sliding sign. Iodopovidone was effective in inducing pleurodesis in patients with malignant pleural effusion.

\section{REFERENCES}

1. Porcel J, Light R (2013): Pleural effusions, Dis. Mon., 59: 29-57.

2. Heffner J (2010): Management of the patient with a malignant pleural effusion, Semin. Respir. Crit. Care Med., 31: 723-733.

3. Rodriguez-Panadero F, Antony V (1997): Pleurodesis: state of art, Eur. Respir. J., 10: 1648-1654.

4. Heffner J, Nietert J, Barbier C (2000): Pleural fluid $\mathrm{pH}$ as a predictor of pleurodesis failure, Chest, 117: 87-95.

5. Qureshi N, Rahman N, Gleeson F (2009): Thoracic ultrasound in diagnosis of malignant pleural effusion, Thorax, 64: 139.

6. Kabil A, Ouf F, Arafa T, Awad N, Faramawy M, Yassein H (2013): CT guided Abrams needle pleural biopsy versus medical thoracoscopy for diagnosis of cases with undiagnosed pleural effusion, M.D. thesis. Al-Azhar University.

7. Porcel J, Vives M, Esquerda A, Salud A, Perez B, Rodriguez-Panadero F (2004): Use of a panel of tumor markers (carcinoembryonic antigen, cancer antigen 125 , carbohydrate antigen 15-3, and cytokeratin 19 fragments) in pleural fluid for the differential diagnosis of benign and malignant effusions, Chest, 126(6):1757-1763.

8. Chernow B, Sahn S (1977): Carcinomatous involvement of the pleura and analysis of 96 patients, Am. J. Med., 63: 695-702.

9. Rantanen $\mathbf{N}$ (1986): Diseases of the thorax. Vet Clin North Am., 2: 49-66.

10. Lichtenstein D (2003): Echographie pleuropulmonaire. Re animation, 12: 19-29.

11. Fayiad H, El Hadidy A, Kamel H, Abo Ziad A, Kamal E (2017): Role of chest ultrasound in detecting successful pleurodesis M.D thesis, Cairo University.

12. Morales-Gomez J, Téllez-Becerra J, MartínezOrmen o J (1993): Pleurodesis conyodopovidona en el derrame pleural neoplsico, Rev. Int. Nal. Enf. Resp. Mex., 6:71-74. 